\title{
Toward an agenda for placing migrant hometown associations (HTAs) in migration policy-making discourse in Ghana
}

\author{
Thomas ANTWI BOSIAKOH \\ Department of Sociology, P. O. Box LG 65, University of Ghana, Legon, Ghana. \\ E-mail: tabosiakoh@ug.edu.gh, bosiakoh@gmail.com. \\ Accepted 4 June, 2012
}

\begin{abstract}
Migrant hometown associations (HTAs) are arguably the most recognizable migrant institutions in migration destination countries. As institutions for the welfare of migrants and for the development of migrant home and destination countries, migrant HTAs have engaged the attention of migration scholars for a number of reasons. Their activities straddle across different spheres of endeavours, including adjustment and integration, development, promotion of peaceful co-existence, socio-cultural empowerment, and resolution of conflicts, among others. These activities of migrant HTAs are important in achieving co-development and therefore require policy focus. While it is important to commend Ghana for initiating a process for migration policy development, the discussions and debates show no concern for placing migrant HTAs in the discourse. This paper proposes the possibility of incorporating migrant HTAs in the migration policy development discourse and argues that, giving the kind of activities migrant HTAs in Ghana and elsewhere engage in and the ways in which these associations have control over their members, the associations could serve as very useful platforms for state-migrant engagement which is essential for effective management of migration issues in the country.
\end{abstract}

Key words: Migrant hometown associations, migration policy development, Ghana.

\section{DISCOURSE, POLICY NARRATIVES AND MIGRANT HOMETOWN ASSOCIATIONS (HTAS) IN MIGRATION POLICY-MAKING PROCESS}

The argument that migration policy should be shaped by discourse is a novel one in much of the migration literature (Menz, 2011). In using the concept discourse, this study draws on the work of Schmidt (2000: 7) who submitted that, discourse consists of 'whatever policy actors say to one another and to the public more generally in their efforts to construct and legitimate their policy programmes'. Resonating from this submission are two key elements, namely the fact that: (i) discourse denotes policy ideas and values and (ii) it is interactive in nature and involves communication.

Boswell et al. (2011) recommended policy narratives ${ }^{1}$, emphasizing the importance of policy expertise and

${ }^{1}$ Policy narratives as used by Boswell et al. (2011) refers to the use of empirical claims about the causes and dynamics of the phenomena in question. research in shaping migration policy-making. This paper is an attempt to contribute to the interactive part of the discourse on the Ghanaian migration policy making. While existing scholarship on migration policy does not emphasize the role of discourse, this paper considers it important because it allows various stakeholders in the migration field to make contributions for effective migration policy.

A key area requiring the attention of migration policy makers is policy narratives as suggested by Boswell et al. (2011) which in the framework of this paper is not to make claims about the causes and dynamics about migration but to call for infusion of empirical work in the migration policy-making process/discourse (Figure 1).

The purpose of this paper is to make a case for incorporation of migrant hometown associations (HTAs) ${ }^{2}$

${ }^{2}$ These associations, also called migrant organizations, refer to social groupings formed by migrants from the same origin in their destination' (Silver, 2006: 2). They may be specific to some categories of migrants engaged in some specific activities of interest. 


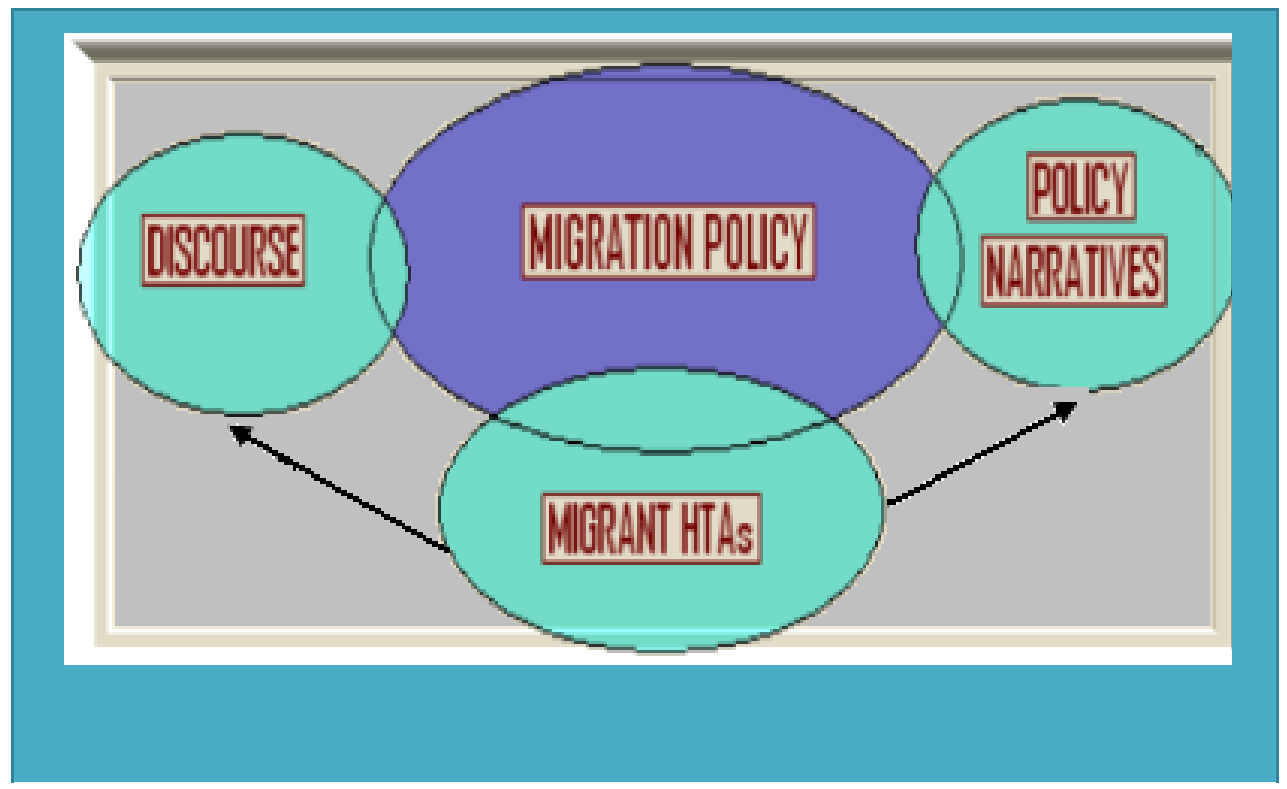

Figure 1. Framework for placing migrant HTAs in migration policy discourse. Source: Author's construct.

in the migration policy-making discourse in Ghana. The paper is basically a policy-advocacy one based on analysis of existing literature on migrant associations in Ghana and elsewhere around the world. The analysis is placed within the contexts of discourse and policy narratives, thus bringing to the spotlight the need to highlight migration stakeholder participation and empirical content in the formulation of migration policy for Ghana. Thus, the paper draws its strength from the survey it makes into the existing literature on migrant associations.

\section{MIGRATION HISTORY IN GHANA AND THE EMERGENCE OF MIGRANT ASSOCIATIONS}

Migration has, for a long time, been part of the people of Ghana. Earliest evidence of human movement in Ghana was towards North Africa in the trans-Saharan caravan trading system in the $1300 \mathrm{~s}$. During this period, there were also human movements in response to war and search for fertile land for agriculture.

Later in the 1400s, Europeans emerged in the west coast of Africa for trade, disrupting the West-North African trading system and later introducing trade in human beings and eventually colonized the people. From the 1800 s to 1950 s, colonization re-configured the face of human mobility in Ghana with introduction of forced labour recruitment policies and the establishment of large cocoa farms and mines which attracted migrants from Ghana and other West African nationals including Nigeria, Mali Ivory Coast, among others. In 1969, Ghana promulgated an Alien's compliance order to expel several West African, but also other migrants who did not have valid documents.

Ghanaians started emigrating in the 1970s and 1980s when the country was faced with socio-economic challenges and frequent military intervention in the political life of the country. During this period, many Ghanaians chose out-migration as the option for dealing with the socio-economic and political challenges that confronted the country. Out migration of Ghanaians continued in the 1990s leading to well established Ghanaian communities in major cities across the world including New York, London, Toronto, Amsterdam and Hamburg, among others.

Also in the 1990s, particularly in 1992, Ghanaians resolved their political challenges with a return to constitutional governance after the 1992 constitution had come to force. Since then, the country has witnessed relative peace compared with her neighbouring countries. Consequent to this development, Ghana has experienced widespread immigration, mostly from the West African sub-region, particularly Nigerians (Antwi Bosiakoh, 2011b; 2011a; 2009).

At the country level, there has also been enormous internal re-configuration of population with several new urban forms and settler communities emerging in Ghana fueled mainly by internal migrants. One corollary of increased migration is the emergence of migrant associations as migrants turn to these associations to take care of their needs. As institutions or organizations for the welfare of migrants and for the development of migrant home and destination countries, migrant associations have engaged the attention of migration scholars for some time now. Part of the reasons for the emergence of migrants associations is that, often, there 
are no formal institutions in migration destination countries that work to promote the welfare of migrants. In this situation, the associations emerge to take care of the problems encountered by the migrants (Okamura, 1983).

In Ghana, migrant hometown associations (HTAs) have been an important institution for migrants, both internal (Obeng, 2010; Tonah, 2008, 2005) and international (Antwi Bosiakoh, 2011a; Owusu, 2000; Eades, 1994) and have become part of the repertoire of voluntary associations in the West African landscape (Little, 1957; Agbese, 1996).

Little (1957) who began writing on migrant associations in West Africa in the 1950s described how the associations catered for the economic, religious or other needs of migrants and also assisted with adaptation of newly arrived migrants to their new environment in terms of companionship, protection and recommendation of appropriate behaviours based on the norms of the host society (Busia, 1950; Acquah, 1958 and Little, 1965).

Eades' (1994: 140 to 174) account of Yoruba presence in northern Ghana in the early post independence period also shows elaborate associational forms (including town parapo (sing.), religious organizations, the Yoruba Community Committee (Ilu Pejo) and the Nigerian Community Committee) with several branches across northern Ghana. Other accounts on migrant associations in Ghana show that, the associations operate under relatively durable organizational structures with well defined tenures of leadership with memberships ranging from just about 20 to as large as 500 .

In general, newer migrants show higher leaning to the associations but leadership positions are often entrusted in the hands of older migrants (Antwi Bosiakoh, 2010; Obeng, 2010). While the associations exist for the migrants, the benefits of their activities transcend the associations (Antwi Bosiakoh, 2011b).

\section{MIGRATION POLICIES AND MIGRATION MANAGEMENT IN GHANA}

Over the past half century since Ghana gained independence, the country has not had a composite policy on migration ${ }^{3}$. This however is not to suggest that the country has not managed migration in any way. There have been several protocols, conventions and legislations with which migration in Ghana has been managed over these years. In a review of these protocols, conventions and legislations, Quartey (2009: 77) argued that, the need for a comprehensive migration policy in Ghana had been recognized, and that, efforts were in place towards formulating one. Thus, according to Quartey, there was national consensus for a one-stop allencompassing migration policy for Ghana for the management of migration in the country (Awumbila Manuh et al., 2011a). In other words, Quartey believes

\footnotetext{
${ }^{3}$ This argument can be extended to the colonial times.
}

there is the need for a composite or better still, a comprehensive migration policy to deal with migration issues in Ghana.

But how have Ghanaians managed migration all these years? In trying to understand migration management process in Ghana over the years, there is the need to appreciate the fact that, Ghana is a member of several international organizations, organizations that have various protocols and conventions guiding human movements. As a member in these organizations, Ghana has been obliged to manage migration in accordance with these protocols and conventions.

In addition, there have been several national legislations that have guided migration management processes in the country. Thus, one can argue that migration management decisions in Ghana have been predicated on two sources of regulations, international protocols and conventions and national legislations and regulations. The international sources include the United Nations (UN), the African Union (AU), the European Union (EU) and the Economic Community of West African States (ECOWAS). Table 1 presents the sources of regulations for migration management decisions in Ghana.

In addition to the international protocols and conventions and the national legislations and regulations, there are a number of national institutions working in diverse ways to help government manage migration in the country. These institutions are varied and include ministries (interior, foreign affairs, women and children's affairs, tourism, employment and social welfare), parastate institutions (Ghana Immigration Service, Ghana Statistical Service, Ghana Refugees Board, Ghana Police Service, The Judicial Service, National Population Council, National Development Planning Commission), and academic institutions (the Centre for Migration Studies, the Regional Institute for Population Studies, among others). In a review of these protocols, conventions and legislations Quartey (2009: 77) and Awumbila et al. (2011a) have argued that, the need for a comprehensive migration policy in Ghana has been recognized, and that, efforts are in place towards formulating one. Thus, according to these studies, there is national consensus for a one-stop all-encompassing migration policy for Ghana for the management of migration in the country.

\section{TOWARD A COMPOSITE MIGRATION POLICY FOR GHANA: THE POLICY-MAKING PROCESS}

Recognizing the need for a composite migration policy, the government of Ghana in 2006 set up Migration unit $(\mathrm{MU})$ at the Ministry of the Interior to facilitate migration policy formulation and also to monitor and evaluate existing laws and procedures on emigration and immigration. Three areas of migration were identified and three technical committees formed around them, namely migration and economic development, labour and 
Table 1. Regulatory framework for migration management in Ghana (Awumbila et al., 2011a; Quartey, 2009).

\section{International legislations}

\begin{tabular}{|c|c|}
\hline & International legislations \\
\hline \multirow{8}{*}{ United Nations } & 1. 1949 convention (migration for employment). \\
\hline & 2. 1951 convention (status of refugees). \\
\hline & 3. 1967 protocol and 1969 conventions (refugee problems in Africa). \\
\hline & 4. 1975 convention (treatment of migrant workers). \\
\hline & 5. 1990 convention (rights of migrant workers and their families). \\
\hline & 6. 2000 convention (against transnational organized crime). \\
\hline & 7. 2002 protocol (smuggling of migrants by land, sea and air) etc. \\
\hline & $\begin{array}{l}\text { 8. Ghana also works with several UN agencies in managing migration including the ILO (convention } 29 \text { on } \\
\text { abolition of forced labour), the UNHCR, UNFPA, UNDP, and IOM. }\end{array}$ \\
\hline \multirow{6}{*}{ African Union } & 1. The Ouagadougou Action Plan. \\
\hline & 2. The Joint Africa-EU declaration on migration and development. \\
\hline & 3. Africa-EU partnership on migration, mobility and employment. \\
\hline & 4. African common strategic position on migration and development. \\
\hline & 5. Migration policy strategic framework for Africa. \\
\hline & 6. AU plan of action on drug control and crime prevention. \\
\hline \multirow{3}{*}{ European Union } & $\begin{array}{l}\text { 1. EU and AU leader met in Rabat and Tripoli in } 2006 \text { to agree on measures to combat human trafficking. } \\
\text { 2. EU and AU leader met to discuss migration in Lisbon in } 2007 .\end{array}$ \\
\hline & $\begin{array}{l}\text { 3. AU-EU partnership on migration, mobility and employment came into being as a Joint Africa-EU strategy } \\
\text { for managing migration. }\end{array}$ \\
\hline & 4. EU-AU leaders' meetings in Burkina Faso in 2002. \\
\hline \multirow{6}{*}{ ECOWAS } & 1. Article 59 of revised ECOWAS Treaty (right of entry, residence and establishment) \\
\hline & 2. 2007 Draft ECOWAS common approach on migration \\
\hline & 3. Free movement within ECOWAS fundamental for ECOWAS integration \\
\hline & 4. Combat human trafficking \\
\hline & 5. Harmonize migration policies \\
\hline & 6. Protect rights of migrants including asylum seekers and refugees, etc \\
\hline \multirow{4}{*}{$\begin{array}{l}\text { Colonial times } \\
1957-1966 \\
1966-1972\end{array}$} & National (internal legislations) \\
\hline & Colonial ordinance (focus on foreign civil servants, traders and missionaries) \\
\hline & Nkrumah's pan-African ideology. 1963 Aliens act (Act 160) entry, residence and employment of aliens \\
\hline & National Liberation Movement (NLM)/Aliens compliance order \\
\hline 1972-1980 Era & $\begin{array}{l}\text { National Redemption Council (NRC), Supreme Military Councils (SMC I and SMCII), Provisional National } \\
\text { Defense Council (PNDC). No explicit policy for managing migration in Ghana }\end{array}$ \\
\hline \multirow{14}{*}{1990 - Present } & 1. Several provisions in the 1992 Constitution. \\
\hline & 2. Refugee law, 1992 (PNDCL 30). \\
\hline & 3. Revised 1994 population policy. \\
\hline & 4. Ghana Investment Promotion Centre Act, 1994 (Act 478). \\
\hline & 5. Children's Act 560 (1998). \\
\hline & 6. Citizenship Act, 2000 (Act 591). \\
\hline & 7. Immigration Act, 2000 (Act 573). \\
\hline & 8. Immigration Regulations, 2001 (L.I. 1691). \\
\hline & 9. The dual citizenship regulation act. \\
\hline & 10. Labour Act, 2003 (Act 651). \\
\hline & 11. Human Trafficking Act, 2005 (Act 694). \\
\hline & 12. The Ghana Investment Promotion Centre (Promotion of Tourism) Instrument, 2005 (L.I. 1817). \\
\hline & 13. Labour Regulations, 2007 (L.I. 1833). \\
\hline & 14. Representation of People's Amendment Act 2007 (Act 669), etc. \\
\hline
\end{tabular}


Table 1. Contd.

\begin{tabular}{ll}
\hline 1. Disembarkation upon approval by an Immigration Officer. \\
2. Travelers to and from Ghana to complete embarkation and disembarkation forms at the exit and entry points. \\
3. Non-ECOWAS nationals requiring visa to enter Ghana. \\
4. Immigrants in Ghana require resident and work permits to stay and work. \\
5. Nationals of ECOWAS member states don't require visa to enter Ghana; they can stay in Ghana for up to 90 \\
days without residence permit, etc.
\end{tabular}

Source: Awumbila Manu et al., 2011a; Quartey, 2009.

irregular migration, and migration policy, information and research.

In addition, migration profile technical working group (TWG) was formed for the preparation of a national migration profile to serve as a policy tool for developing the migration policy. An inter-ministerial team involving five ministries ${ }^{4}$ and four migration-related state institutions ${ }^{5}$ has also been formed to develop migration policy for Ghana with support from the European Union and the International Organisation for Migration (IOM). There is also Migration Management Bureau (MMB), managed by the Ghana Immigration Service and the International Organisation for Migration. Following from these attempts, there have been several national discussions on the framework of the proposed migration policy for Ghana.

While acknowledging that there has been fruitful discourse on the framework of the proposed policy, what stays absent in all these discussions is the recognition of the role of migrant hometown associations, the most recognizable migrant institutions in the migration process, in making migration management (both emigration and immigration) positive for the country. Subsequently, the study attempts an interrogation of the possibility of incorporating migrant hometown associations in the proposed migration policy for Ghana. In doing this, the paper surveys a range of studies on the roles that migrant hometown associations have played in the development processes not only of the countries of origin, but also of destination countries.

\section{MIGRANT HOME TOWN ASSOCIATIONS AND MIGRATION MANAGEMENT}

\section{Migration policy vision}

The goal of migration policy is to provide a framework with which to manage migration (both immigration and emigration) in order to achieve the full benefits and to

\footnotetext{
${ }^{4}$ The five ministries are the Employment and Social Welfare, Interior, Foreign Affairs, Finance and Economic Planning, and Tourism.

${ }^{5}$ The Ghana Statistical Service (GSS), Ghana Immigration Service (GIS), Ghana Trades Unions Congress (TUC), and the National Population Council (NPC).
}

minimize the costs of the migration process. Thus, migration management is at the heart of every migration policy. For many developed economies/countries, migration policies have focused on measures to restrict entry, albeit unsuccessful in the process.

For some other jurisdictions, entry restrictions are provided and in addition, elaborate programmes are laid down for their integration into the mainstream society. In all these cases, there are serious challenges in managing migrants. For instance decisions by political leadership on migration are often predicated on conditions within the country and the ways in which these decisions are accepted by the populace in a political sense.

Thus, the aspiration of every country in relation to migration management is to formulate policy(ies) that ensure effective and efficient management. A number of issues readily come to the fore when thinking about managing migration in Ghana in an effective and efficient way. These issues include remittance generation, acquisition and use of expert skills (brain drain, brain gain and brain circulation) investment promotion, promotion of peaceful co-existence, socio-cultural empowerment, and resolution of conflicts, among others.

\section{Migrant HTAs as platforms for migration management: Literature evidence}

Migrant hometown associations have often been portrayed in positive light. In this section, the study present four quick snapshots of the ways in which migrant hometown associations have been portrayed in the literature with the view to propose incorporation of migrant HTAs in the migration policy development discourse in Ghana, and by extension, other national jurisdictions.

\section{Migrant HTAs are well structured}

Studies on migrant associations show that, the associations are well structured (Antwi Bosiakoh, 2010; Obeng, 2010) and are engaged in all manner of activities in the migration destination and origin places. The associations operate under relatively durable organizational structures (led by presidents or chairpersons, 
secretaries and treasurers, financial secretaries etc) who are elected periodically with well defined tenures of leadership. Leadership responsibilities are often entrusted in the hands of older migrants, who by virtue of their long stay in the migration destination area and possibly high stake in the whole migration process have gained experience in the host country and are able to share them with newer migrants.

One way that migration policy decision could be aligned with migrant associations, in particular the way the associations are structured and therefore ensure effective migration management in the country is an explicit recognition of migrant associations by both the migrant origin and destination countries.

Organized around this kind of durable and well recognized leadership in migrant destination places, this paper proposes that migrant associations could be leveraged by the state to serve as very useful platforms for state-migrant engagement which is essential for effective management of migration. If for nothing, the associations provide a rallying point for the migrants, rallying point which the state can tap into for statemigrant engagement.

\section{Migrant HTAs check behaviour of members}

Migrant HTAs are also endowed with influence over their members. The associations have control over their members such that, they have in place 'behaviour checking measures' for prospective members to follow before one's admission into the associations (Antwi Bosiakoh, 2010; Obeng, 2010). One such association in Ghana is the Nigerian Committee of Brothers association in Accra. For this association, a person gets membership into it only when thorough study has been done on the prospective member to identify what the prospective member does for a living.

Prospective members also serve three-month probation before membership decision is reached. In addition, members monitor the activities of each other to ensure that, the name of the association (and of course Nigerians in general) is not dragged in the mud. These measures are largely to ensure that members (both new and old) are of "good character" (Antwi Bosiakoh, 2010:47). Thus in the opinion of this paper, the benefits emanating from migrant associations ensuring that members are of good behaviour ${ }^{6}$ can safely be incorporated into migration policy in Ghana such that, policy posture towards the formation of associations by migrants (both internal migrants and other immigrants) could be viewed in a positive manner by the state and if possible encouraged.

\footnotetext{
${ }^{6}$ This is generic implying that migrants play out their activities in the host country within the confines of the law.
}

\section{Migrant HTAs and conflict resolution}

Another area that migrant associations can be relied upon is in relation to social cohesion and conflict resolution not only among the migrants but also with their host people and in migrant communities as a whole. Migrant associations are created out of informal social networks. In the process of settling in migration destination places, migrants usually form networks based on several factors including nationality and identity among others. These social networks eventually give way to migrant associations (Pojmann, 2007; López et al., 2001). Thus, migrant associations are viewed as formal manifestations of migrant social networks. These networks embedded in migrant associations are relied upon by the associations in the migration destination areas to achieve social cohesion and also resolve conflict (Awumbila Alhasan et al., 2011b; Tonah, 2003, 2005, 2008).

In a study on the presence of the Fulani in Ghana for example, Tonah (2005) demonstrates how the migrant Fulani association (Bantari) in Wungu, northern Ghana works to promote peace and cordial relationship between the migrant Fulani community and the indigenous Mamprusi people. Tonah demonstrates further that in recent times, the association not only promotes peace and cordial Fulani-Mamprusi relationships, but has been involved with conflict resolution in Wungu and its environs. There are incidences of farmer-herder conflicts (Tonah, 2003), which often end up with Bantari leaders, and as leaders of the association and the Fulani communities in the area, they mediate, and resolve them in the name of the association.

In a study of the Asanteman immigrant association in New York, Atta-Poku (1996) reports that, leaders of the association employ prolific references to the Asante tradition and western court system to resolve disputes between their members and also between their members and members of the host society. Arbiters often make references to the traditional obligations and norms of aggrieved parties and encourage them to take softened positions. Atta-Poku observes that, the arbitration role played by the association go a long way to ease situations which otherwise would have flammable consequences (Atta-Poku, 1996: 69).

\section{Migrant HTAs and development}

Migrant HTAs have in recent times assumed the status of 'development agents' or 'development intermediaries'. In most developing countries where governments have become lethargic in providing basic facilities, migrant HTAs have shown to be faithful intermediaries and can be relied upon for the provision of basic facilities (Mumuni, 2007). For instance, Owusu (2000) has demonstrated that, Ghanaian migrant associations in Toronto, Canada regularly donate equipment, drugs and books to 


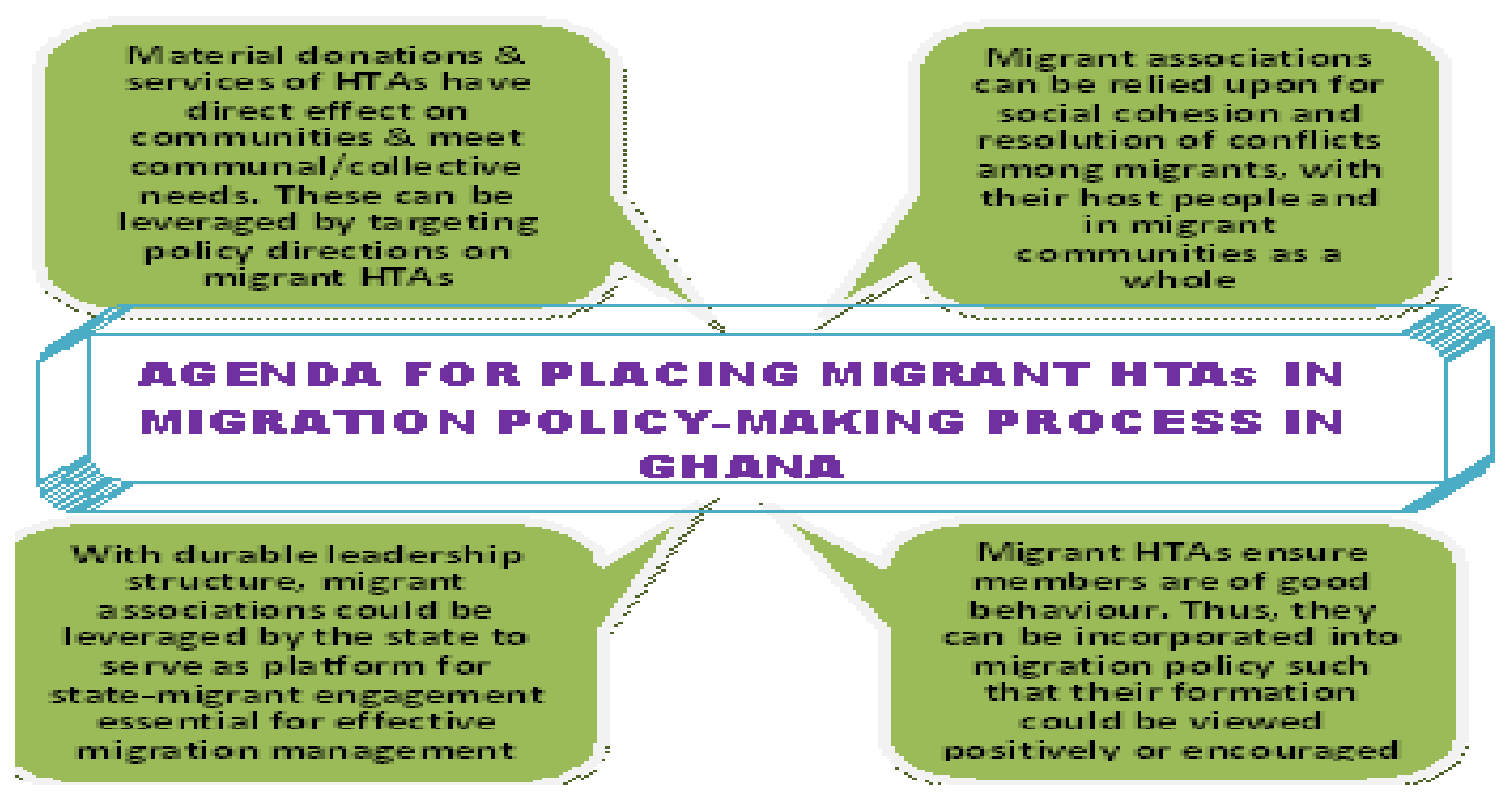

Figure 2. A summary model for placing migrant HTAs in migration policy discourse. Source: Author's Construct.

various institutions in Ghana (Owusu, 2000:1174) for collective effect.

Other HTAs provide basic infrastructure through the construction of clinics, classrooms, parks, and homes, and in addition, donate money for special occasions or circumstances, such as a religious celebration or to repaint or repair a local church (Orozco and Rouse, 2007).

Recent empirical findings on Nigerian migrant associations in Ghana have also found the activities of the associations to be useful for social development in Ghana. The social activities of the associations (charity and philanthropic) make them useful social development agents in Ghana (Antwi Bosiakoh, 2011b).

In a survey of migrant hometown associations in Germany, Schröder (2006) observed that, half of the associations had carried out non-profit activities in Ghana (Schmelz, 2009). In Mexico, donation of HTAs are said to be more than $50 \%$ of the money in municipal public works budgets. In towns with less than 1,000 people, donations from HTAs sometimes amount to up to seven times the public works budget (Orozco, 2007). These donations provide significant aid to vulnerable communities where the capacity of local government has fallen short. In Nigeria for example, Honey and Okafor (2008) have argued that migrant hometown associations have been designated by the government as 'shadow states' and 'development agencies' because they have taken on tasks that both state and federal governments are no longer assuming.

Some activities of migrant hometown associations such as concerts and beauty pageants also promote culture and solidarity in the migration destination communities. For example, the Fante Benevolent Society of Chicago has a mission to promote Ghanaian traditions and values in the Diaspora. This, the association does by helping with the "neighbouring and outdooring ceremonies" when a child is born.

Meanwhile, in the Netherlands, Ghanaian HTA activities often focus on burial traditions (Orozco and Rouse, 2007). While these activities in themselves do not constitute development, they nonetheless help in the promotion of Ghanaian culture abroad. Additionally, these activities provide support to the migrant communities in the host country.

\section{A SUMMARY MODEL FOR PLACING MIGRANT HTAS IN MIGRATION POLICY DISCOURSE}

In calling for attention to place migrant hometown associations (HTAs) in migration policy-making discourse in Ghana, this paper draws attention to four roles that migrant hometown associations play, not only in the migration destination places but also in migration origin places (Figure 2). The first relates to the relatively durable organizational structures that migrant HTAs possess. These structures, in the estimation of this paper could be leveraged by the state for state-migrant engagement essential for effective migration management in Ghana.

The second role migrant HTAs play is in ensuring good behaviour among the members. This role of migrant HTAs could be incorporated into migration policy such 
that, policy posture towards the formation of such associations would be viewed positively by the state and if possible, encouraged.

The third role of migrant HTAs is in the area of social cohesion and conflict resolution. As shown earlier, migrant HTAs work as peace makers with, and among migrants as well as between migrants and members of their host communities. This role, just like the other roles outlined can be relied upon by the state to ensure peace and social cohesion in migrant communities.

Also material donations from migrant HTAs meet the needs of communities and therefore have collective/ communal effects on migration origin places. Thus, giving the roles and activities of migrant HTAs, there is the need to incorporate these associations into migration policy discourse in Ghana.

\section{ACKNOWLEDGEMENTS}

This paper was first presented at the Fifth Annual Faculty of Social Science Colloquium at the University of Ghana, Legon, Accra on the theme 'Social Sciences and Public Policy', 17-18 Nov., 2011. The author is grateful to all the participants for their useful comments and also to the two anonymous reviewers who painstakingly read through the paper and pointed out areas for revision.

\section{REFERENCES}

Acquah I (1958). Accra Survey. University of London Press, London.

Agbese PO (1996). Ethnic conflicts and hometown associations: An analysis of the experiences of the Agila development association. Afr. Today 43(2):139-156.

Antwi Bosiakoh T (2009). Understanding Migration Motivations in West Africa: The Case of Nigerians in Accra, Ghana. Legon J. Sociol. (Dec., 2006-June, 2009): 3(2):93-112.

Antwi Bosiakoh T (2010). Leadership and membership structure of migrant Associations: The case of Nigerian migrant associations in Accra, Ghana. J. Soc. Sci. Public Policy 2:37-51.

Antwi Bosiakoh T (2011a). Nigerian Migration to Ghana: History, Motivations and Associational Forms. Saarbrücken, Germany: Lambert Academic Publishing.

Antwi Bosiakoh T (2011b). The Role of Migrant Associations in Adjustment, Integration and Social Development: The Case of Nigerian Migrant Associations in Accra, Ghana. Ghana J. Dev. Stud. 8(2):64-83.

Atta-Poku A (1996). Asanteman immigrant ethnic association: An effective tool for immigrant survival and adjustment problem solution in New York City. J. Black Stud. 27(1):56-76.

Awumbila M, Alhasan O, Badasu DM, Antwi Bosiakoh T, Tetteh EK (2011b) . Socio-Cultural Dimensions of Migration in Ghana. Migration Studies Technical Paper Series, Centre for Migration Studies. Accra: Woeli Publishing Services p.3.

Awumbila M, Manuh T, Quartey P, Antwi Bosiakoh T, Tagoe CA (2011a). Migration and Mobility in Ghana: Trends, Issues, and Emerging Research Gaps. Accra: Woeli Publishing Services.

Boswell C, Geddes A, Scholten P (2011). The Role of narratives in migration policy-making: A research framework. Br. J. Pol. Int. Rel. 13(1):1-11.

Busia KA (1950). Report on social survey of Sekondi-Takoradi. Crown Agents for the Colonies. Accra.
Eades JS (1994). Strangers and Traders: Yoruba Migrants, Markets and the State in Northern Ghana'. Trenton, NJ: Africa World Press Incorporated.

Little K (1957). The role of voluntary associations in West African urbanization. American Anthropologist, UX (4):579-596.

Little K (1965). West Africa Urbanization: A Study of VoluntaryAssociation in Social Change. Cambridge: Cambridge University Press.

López FH, Escala-Rabadan L, Hinojosa-Ojeda R (2001). Migrant associations, remittances, and regional development between Los Angeles and Oaxaca, Mexico. Research Report Series North American Integration and Development Center School of Public Policy and Social Research p.10.

Menz G (2011). Framing Competitiveness: The advocacy of articulating migration as a human resources strategy. Paper presented at the Biannual Conference of the European Union Studies Association (EUSA) in Boston, Massachusetts 3-5 March.

Mumuni D (2007). 'To whom much is given, much is expected'; involving the migrant in community development. Case of the west Mamprusi district of Northern Ghana. Amsterdam: University of Amsterdam.

Obeng MKM (2010). Hometown association and community development: A case study of Oboman Development Association. Master of Philosophy Thesis submitted to the Department of Sociology, University of Ghana, Legon.

Okamura JY (1983). Filipino Hometown Associations in Hawaii. Ethnology 22(4):341-353.

Orozco M (2007). Hometown Associations and Opportunities for Development. Washington D.C.: Inter-American Dialogue.

Orozco M. Rouse R (2007). Migrant Hometown Associations and Opportunities for Development: A Global Perspective. Washington D.C.: Inter-American Dialogue.

Owusu TY (2000). The role of Ghanaian immigrant association in Toronto, Canada. Int. Migr. Rev. 34(4):1115-1181.

Pojmann W (2007). Organising women migrants: The Filipino and Cape Verdean women's associations in Rome. Migr. Lett. 4(1):29-39.

Quartey P (2009). Migration in Ghana: A country profile. Geneva: International Organization for Migration.

Schmelz A (2009). The Ghanaian Diaspora in Germany: Its Contribution to Development in Ghana. Deutsche Gesellschaftfür Technische Zusammenarbeit (GTZ) GmbH Economic Development and Employment Division, Migration and Development Sector Project.

Schmidt VA (2000). The politics of economic adjustment in France and Britain: Does discourse matter? Paper presented at the European University Institute, Florence, 5, May.

Schröder S (2006). Die ghanaische Diaspora in Deutschland Entwicklungsmotor für ihr Heimatland? Beiträge der ghanaischen Diaspora in Deutschland und ihrer Organisationen zur Entwicklung ihres Heimatlandes, Diploma Thesis, Humboldt University Berlin, Department of Geography.

Tonah S (2003). Conflict and consensus between migrant Fulani herdsmen and Mamprusi farmers in Northern Ghana. In Kroger Franz and Barbara Meier (eds.). Ghana's North: Research on Culture, Religion and Politics of Societies in Transition. Frankfurt: Peter Lang.

Tonah S (2005). Fulani in Ghana: Migration history, integration and resistance. Accra: Research and Publication Unit of the Department of Sociology, University of Ghana, Legon.

Tonah S (2008). Migration, resource use, conflicts, and stakeholders in the Middle Volta Basin. In: Amoah CM, Adiku SGM and Owusu EO (Eds.), New developments on health, agricultural resources and socio-economic activities in the Volta Basin, Ghana. Accra: Volta Basin Research Project (VBRP), University of Ghana, Legon pp.136154. 